\title{
PEMBERDAYAAN EKONOMI KERAKYATAAN MELALUI LEMBAGA KEUANGAN SYARÎ'AH
}

\author{
Wadhan \\ (D osen Jurusan Tarbiyah STA IN Pamekasan, JI. Raya Panglegur Km. 04 \\ Pamekasan)
}

\begin{abstract}
Abstrak:
UKM is the business maker of the lowest level marketing. The aim of the empowerment of UKM is that to grow and to accelerate a strong business ability, independent, and competition power against abroad products. It is a proper choice to use Syariah banking for UKM financing. Syariah banking has a great opportunity to develop macro banking in order to reform Indonesian economy.
\end{abstract}

Kata kunci:

ekonomi kerakyatan, keuangan syarî'ah, UKM, dan ribâ

\section{Pendahuluan}

Krisis global yang hampir dialami oleh semua negara memiliki pengaruh yang signifikan terhadap semua bidang terutama bidang ekonomi. A merika Serikat yang merupakan negara maju juga terkena dampak krisis global di bidang ekonomi. Bahkan negara yang dikenal dengan negara super power ini melakukan Pemutusan Hubungan Kerja(PHK) terhadap karyawan sebesar $20 \%$ dari total $\mathrm{PHK}$ yang dilakukan di seluruh dunia yang berjumlah 2 juta orang. Ini berarti negara yang super power ini melakukan PHK atas 400.000 orang karyawan dari berbagai level perusahaan. ${ }^{1}$

Indonesia sebagai negara berkembang di mana populasi penduduknya yang sangat tinggi menduduki urutan ketiga di dunia

\footnotetext{
1 Perusahaan tambang terbesar BHP Billinton mem-PHK 6000 karyawan akibat krisis global (Metro TV, Suara Anda, Rabu: 21 Januari 2009). Sedangkan pada periode 1-9 Januari 2009 terdapat 200.000 karyawan yang di-PHK (Trans TV, Good Morning, Kamis: 22 januari 2009).
} 
setelah Cina dan India tentunya sangat merasakan dampak krisis global ekonomi, dengan bertambahnya tingkat pengangguran, meningkatnya laju inflasi, ${ }^{2}$ tingkat suku bunga bank (SBI) yang tinggi, dan terpuruknya sektor riil di tingkat paling bawah dan menengah, yang dalam hal ini adalah UKM (Usaha Kecil dan Menengah).

Banyak perbankan konvensional yang sudah menyalurkan kredit bagi UKM dan usaha mikro sebesar Rp. 11, 4 Trilliun yang merupakan $35 \%$ dari komitmen kredit sebesar 30,8 Trilliun pada tahun 2002. ${ }^{3}$ Tetapi karena tingginya tingkat Suku Bunga Bank (SBI), sehingga UKM ini susah untuk berkembang apalagi untuk bisa bersaing dengan produk dari luar negeri. Sekarang banyak pelaku bisnis di tingkat bawah (UKM) mencari pendanaan atau pembiayaan alternatif melalui lembaga keuangan syarî'ah (Bank Syariah). Alasannya sangat sederhana, yaitu karena Bank Syariah merupakan jawaban kebutuhan masyarakat bagi terwujudnya sistem perbankan syarî'ah yang sesuai dengan syarî'ah serta merupakan institusi keuangan yang dapat memberikan jasa keuangan yang sesuai dengan syarî'ah. ${ }^{4}$

\section{UKM sebagai Tonggak Pelaku Bisnis Level Dasar.}

Sektor usaha kecil dan menengah memiliki peran yang cukup besar dalam keseluruhan pembangunan ekonomi bangsa. Pada masa krisis, yaitu tahun 1998 jumlah pelaku usaha kecil dan menengah (UKM) mencapai 99,8 \% dari total pelaku ekonomi kita, sementara sisanya hanya 0,2 \% merupakan pelaku usaha besar. Dengan demikian, mayoritas pelaku ekonomi kita adalah usaha kecil dan menengah dan koperasi. Di samping itu, sektor ini juga menyerap 88,3 \% total angkatan kerja di Indonesia. Dari keseluruhan unit usaha

\footnotetext{
2 Inflasi merupakan suatu proses atau peristiwa dalam perekonomian dimana terjadi harga dari semua barang naik secara terus menerus selama periode tertentu yang diakibatkan karena terganggunya keseimbangan antara arus uang dan arus barang. 3Nanang Widananto, "Komitmen Memperkuat Daya Saing UKM", Jurnal M anajemen BPFE U nversitas Diponegoro Semarang, (Oktober, 2002), hlm. 1

4Lihat Undang-undang No. 23 Tahun 1999 tentang Bank Indonesia (Jakarta: Bank Indonesia, 1999)
} 
kecil, $54 \%$ di antaranya bergerak di sektor pertanian, $23 \%$ di sektor perdagangan dan $10,6 \%$ adalah unit usaha olahan. ${ }^{5}$

Pemerintah melalui Undang-undang No. 9 Tahun 1995 mengenai usaha kecil mempunyai komitmen untuk melakukan pemberdayaan usaha kecil. Sebagaimana disebutkan dalam pasal 4, pemberdayaan usaha kecil tersebut ditujukan untuk: (1) Menumbuhkan dan meningkatkan kemampuan usaha yang tangguh, mandiri, dan meningkat; (2) meningkatkan peranannya dalam pembentukan produk nasional, perluasan kesempatan kerja dan berusaha, peningkatan ekspor, serta peningkatan dan pemerataan pendapatan untuk mewujudkan dirinya sebagai tulang punggung serta memperkokoh struktur perekonomian nasional; (3) dalam mewujudkan tujuan tersebut, pemerintah diharuskan (sebagaimana pasal 6) membuat kebijakan yang meliputi beberapa aspek, yaitu; (a) Pendanaan, (b) Persaingan, (c) Prasarana, (d) Informasi, (e) Kemitraan, (f) Perizinan usaha, dan (g) Perlindungan. 6

Sedangkan dalam pasal 14 Undang-undang tersebut, pemerintah bersama dunia usaha dan masyarakat berkewajiban melakukan pembinaan dalam berbagai aktivitas usaha yaitu produksi dan pengolahan, pemasaran, sumber daya manusia dan teknologi.7

Berkenaan dengan pendanaan UKM, menurut pasal 21 Undang-undang tersebut, dapat berasal dari berbagai sumber dana, yaitu; (1) kredit perbankan, (2) pinjaman lembaga keuangan bukan bank, (3) modal ventura, (4) pinjaman dari dana penyisihan sebagian laba perusahaan BUM N, (5) hibah, dan (6) jenis pembiayaan lainnya. 8

Berdasarkan pengamatan dan pengalaman dari beberapa ahli yang peduli dengan UKM, terdapat beberapa kendala yang dihadapi oleh UKM di antaranya: Pertama, sulitnya pihak UKM untuk berhubungan dengan pihak perbankan, khususnya yang untuk nasabah yang bergerak di sektor mikro. ${ }^{9}$ Kedua, tidak tercakupnya

5aka Isgiyarta, Membangun Sinergi BANK- BUMN- UKM Problem dan Solusinya, makalah disampaikan dalam Forum Diskusi Ekonomi II Tahun 2004, (Semarang: 20 Juli 2004), hlm. 1

6 Lihat Undang-undang Republik Indonesia No. 9 tahun 1995 tentang Usaha Kedil, (Jakarta: Kementrian Koperasi dan UKM, 1995).

7 lbid.

8 Ibid.

9 Sektor atau usaha mikro yaitu usaha yang kreditnya sampai dengan Rp. 50 juta. 
jaminan yang dimiliki, untuk memperoleh kebutuhan modal kerja dan investasi. Ketiga, Kurangnya kemampuan manajemen (management skill). Keempat, Kurangnya informasi pasar yang diperoleh pihak UKM untuk memasarkan produknya, sehingga ada beberapa nasabah UKM pemasarannya melalui pihak ketiga. 10

Pangsa kredit UKM menunjukkan peningkatan signifikan dengan pertumbuhan 10,9 \%, artinya dari sektor ini diharapkan berperan dalam pengentasan kemiskinan. Fasilitas dan dukungan teknis merupakan pelumas untuk percepatan business performance UKM. Dalam pengembangan kelembagaan pemerintah dan perbankan secara konseptual membentuk pola- pola kerja antar lembaga terkait, hanya dalam tataran operasional banyak mengalami kendala lapangan. Kendala seperti miskoordinasi antar lembaga, minimnya informasi pengetahuan dan teknologi, lambannya pelayanan instansi terkait sebagainya menurunkan daya saing produk UKM sendiri sehingga mengakibatkan turunnya Revenue mereka sendiri. Menurunnya revenue berpotensi pada macetnya pengembalian kredit.

Dari sisi perbankan, business plan menyalurkan kredit kepada UKM adalah paling reliable dengan resiko kecil untuk kondisi sekarang. Indikasi turunnya daya saing produk Indonesia di luar negeri, memang dapat terjadi karena banyak faktor, tetapi khususnya produk- produk UKM sebagian karena ketidakmampuan pengusaha untuk mempertahankan kualitas dan mengembangkan keunikan atau keorisinilannya. Memenangkan persaingan pada pasar dunia membutuhkan kebijakan atau kemauan politik yang menopang program- program komprehansif yang nyata.11

Pertumbuhan daya saing adalah kunci pengkatan pendapatan UKM. Suntikan pemerintah berupa modal sulit bergulir bila kesinambungan produk UKM itu sendiri mengalami stagnasi sehingga nilai produk pada tahun- tahun berikutnya kurang bersaing. Alokasi terbesar dari kredit UKM adalah membeli bahan baku dan bahan penolong bahkan sebagian harus impor. Belanja teknologi

10A frizal Naim, Peranan Perbankan dalam M empermudah Penyaluran Kredit kepada U KM, makalah disampaikan dalam Forum Diskusi Ekonomi II Tahun 2004, (Semarang: 20 Juli 2004), hlm. 1

11Widananto, “Komitmen Memperkuat Daya Saing UKM", hlm. 1 
sedikit tetapi belanja $R \& D$ tidak ada sama sekali. Untuk riset dan pengembangan produk sering menjadi kendala pada UKM dan usaha mikro. Program pendampingan UKM yang pernah dilakukan pemerintah bebarapa waktu lalu kurang responsif pada kendala $R \& D$ ini.

Tindakan nyata untuk membangun daya saing produkproduk UKM adalah mengembangkan program nasional dan daerah untuk menyusun UKM. Produk program dalam kerangka kebijakan desain industri nasional. Dalam program produk itu tercakup strategi dan teknis operasional sebuah produk unggulan. Pemerintah selaku fasilitator juga tidak hanya menyodorkan kertas blanko, tetapi merangkul mereka untuk bersama- sama mendasar keluar dari situasi menunggu dan bertahan menuju suasana kompetisi. Bukan zamannya lagi menunjukkan keunggulan komparatif seperti upah buruh yang rendah, tetapi saatnya menunjukkan keunggulan kompetitif seperti desain dan kualitas produk adalah andalan baru bagi UKM.12

Kebijakan pemerintah yang tidak proporsional adalah salah satu penyebab tidak tumbuhnya perekonomian nasional. Hal ini tercermin dari kurangnya keberpihakan pemerintah terhadap UKM dibanding pengusaha besar (konglomerat). Padahal kontribusi UKM sangat besar dalam penyerapan tenaga kerja. Di tengah stagnasi perekonomian nasional, UKM telah membuktikan perannya melalui stabilitas pertumbuhan yang pesat.13 Ada dua alasan penting mengapa UKM mempunyai peran strategis dalam struktur ekonomi Indonesia.14 Pertama, jumlahnya banyak dan terdapat pada setiap sektor ekonomi. Kedua, potensi penyerapan tenaga kerja besar. Tiap unit investasi UKM bisa menciptakan lebih banyak kesempatan kerja bila dibandingkan dengan investasi yang sama pada usaha besar.

Dari sisi perbankan, pemberian kredit UKM juga menguntungkan. Pertama, tingkat kemacetan kecil karena kepatuhan nasabah UKM lebih tinggi dibadingkan dengan nasabah usaha besar. Kedua, pemberian kredit ke UKM mendorong penyebaran resiko,

12lbid, hlm. 2.

13Muchammad Hariyanto, "Revitalisasi UKM dalam Membangun Ekonomi Nasional", Jurnal M anajemen BPFE U nversitas D iponegoro Semarang, (September 2002), hlm. 1

14 Ibid., hlm. 19 
karena penyaluran kredit usaha kecil dengan nominal kredit yang kecil memungkinkan bank memperbanyak nasabah. Kredit tidak terkonsentrasi pada satu kelompok atau satu sektor usaha. Ketiga, suku bunga kredit pada tingkat bunga pasar bagi UKM bukan merupakan masalah utama sehingga bank- bank memperoleh pendapatan bunga yang memadai.

Namun ada masalah mendasar, bank komersial kurang percaya memberikan kredit ke UKM. Perbankan tidak memiliki SDM yang secara khusus menilai efisiensi proposal proyek yang diajukan UKM. Akibatnya, UKM rentan bangkrut dan sangat tergantung pada individu yang disebut entrepreneur. Selama ini pengembangan UKM masih diprioritaskan pada aspek pendanaan saja, sedangkan aspek kelembagaan, operasional dan pemasaran belum dikembangkan secara baik. UKM membutuhkan intervensi langsung dari pemerintah dalam berbagai aspek antara lain: pendanaan, kelembagaan, operasional, dam pemasaran. ${ }^{15}$ Pendanaan, pemberian kredit dengan skim yang berorientasi profit dan bagi hasil harus lebih ditingkatkan oleh pemerintah. Tanggungjawab antara pemerintah dan UKM harus seimbang dengan akuntabilitas yang transparan untuk mencegah kredit macet.

Kelembagaan, perlu reformasi dan birokrasi secara total. Perizinan satu atap dan satu pintu (one stop service) dalam bentuk Unit Layanan Teknis (UPT) di tingkat kabupaten dan kota. Ada tiga model yang dapat dimplementasikan. Pertama, unit pelayanan satu atap tapi administrasinya tetap dilayani masing- masing lembaga regulasi. Kedua, unit pelayanan terpusat, menyediakan koordinasi administrasi dan infrastruktural, tapi layanan langsung ditangani lembaga regulasi masing- masing. Ketiga, unit pelayanan satu pintu, penyedian layanan tertentu didelegasikan pada unit ini. Lembaga regulasi sifatnya hanya mengontrol dan mengevaluasi keberadaan unit.

Pertumbuhan UKM secara berkualitas memang diharapkan banyak pihak, sebab UKM yang sehat diyakini mampu mendongkrak kucuran kredit perbankan. Pertumbuhan kredit UKM cenderung lebih tinggi dibandingkan kredit secara total. Itu menunjukkan UKM memiliki potensi besar untuk diolah dan dimanfaatkan perbankan. Sayangnya, perbankan sering terbentur kendala teknis. Di antaranya,

15lbid., hlm. 20. 
kemampuan dan kompetensi yang berbeda- beda pada setiap bank. Paket kebijakan perbankan tentang pemberian insentif pembiayaan UKM dinilai belum memperlihatkan hasil maksimal. ${ }^{16}$

\section{Pemberdayaan UKM melalui Bank Syari'ah}

Menurut pasal 21 Undang-undang No. 9 Tahun 1995 tentang Usaha Kecil, pendanaan UKM berasal dari kredit perbankan. Dalam tulisan ini, ia lebih dispesifikasikan pendanaan yang berasal dari bank syari'ah. Sebagian masyarakat berpendapat bahwa perbankan syarî'ah bukan pelengkap, melainkan sebagai alternatif yang harus dipilih untuk menggantikan perbankan konvensional. Pendapat ini berkeyakinan bahwa konsep perbankan syarî'ah lebih unggul daripada perbankan konvensional. Namun sebagian lagi berpendapat bahwa perbankan syarî'ah pada dasarnya sama saja dengan perbankan konvensional, sehingga perbankan syarî'ah bukan sebagai alternatif dan bahkan juga bukan sebagai pelengkap, bila pada akhirnya praktek perbankan syarî'ah tidak jauh berbeda dengan perbankan syarî'ah. ${ }^{17}$

Sistem perbankan syarî'ah adalah sebuah sistem yang akan dapat menciptakan perekonomian yang lebih stabil, lebih adil, dan efisien. Sistem perbankan syarî'ah akan fokus pada proyek terbaik, bukan pada besarnya agunan serta berlaku pepatah lama "ringan sama dijinjing berat sama dipikul". Bagi umat Muslim, bank syarî'ah memberikan jaminan ketenangan bagi orang kelebihan dana untuk menyimpan uangnya dan bagi yang kekurangan dan untuk meminjamnya, karena di dalam produk bank syarî'ah tidak mengenal adanya unsur ribâ (bunga). Bank syarî'ah mempunyai manfaat, yaitu: (1) Saling membantu di antara masyarakat demi kebaikan; (2) menghindari adanya dana menganggur (idle fund); (3) tidak ada unsur ribâ (bunga); (4) investasi yang dilakukan adalah halâl bagi masyarakat dan (5) menggunakan sistem bagi hasil, sehingga jika

\footnotetext{
16 Jawa Pos, “Y ang Layak D apat Kredit M eningkat", (2 Januari 2008), hlm. 5 17Mulya Siregar, Perbankan Syariah: Alternatif atau Pelengkap, makalah disampaikan dalam Seminar Nasional Shari'ate Economic Activity (SEHATI) di Universitas Diponegoro Semarang, (Semarang: 10 A gustus 2003), hlm. 1
} 
mendapat keuntungan banyak maka kewajibannya harus besar, tetapi jika keuntungannya kecil, maka kewajibannya juga kecil. 18

Selain itu, sistem perbankan syarî'ah sangat memperhatikan azas kemaslahatan bagi orang banyak, sehingga pembiayaan yang dilakukan oleh bank syarî'ah harus menghindari kemungkinan halhal yang merusak moral masyarakat dan lingkungan serta harus memenuhi kriteria halâl menurut syarî'ah Islâm. Maka dapat dimaklumi bidang usaha yang dapat dibiayai oleh bank syarî'ah akan terseleksi atau adanya screening terhadap bidang usaha yang akan dibiayai.

Bank syarî'ah merupakan bank yang beroperasi dengan tidak mengandalkan pada bunga. Bank yang tanpa bunga ini merupakan lembaga keuangan yang beroperasional dan produknya dikembangkan berlandaskan al-Qur'ân dan al-ㅂadîts atau prinsipprinsip syarî'ah. ${ }^{19} \mathrm{Hal}$ ini terutama berkaitan dengan tata cara bermuamalat secara Islâm, seperti menjauhi praktek- praktek yang dikwatirkan mengandung unsur ribâ dan diisi dengan kegiatankegiatan investasi atas dasar bagi hasil dan pembiayaan perdagangan. 20

Pengembangan bank syarî'ah di Indonesia perlu dilakukan dengan memperhatikan kebutuhan dan harapan yang beragam para stakeholders perbankan syarî'ah yang terdiri atas: (a) Bank Umum Syarî'ah, unit- unit syarî'ah, BPRS, (b) Bank Indonesia sebagai pengatur dan pengawas bank, (c) DSN (Dewan Syariah Nasional), DPS (Dewan Pengawas Syariah), (d) Badan Arbitrase Muamalat Indonesia, (e) lembaga keuangan syarî'ah lainnya, seperti Takâful, Bayt al-Mâl wa alTamwîl, BAZIS, (f) lembaga pembuat kebijakan lainnya, yakni Departemen Keuangan dan BAPEPAM, (g) Perguruan tinggi yang berkaitan dengan pendidikan ekonomi dan keuangan syarî'ah, dan (h) masyarakat pada umumnya. ${ }^{21}$

\footnotetext{
${ }^{18}$ Christianto, M odul Ekonomi; U ntuk SM A/ M A Semester Genap sesuai Kurikulum KTSP, (Solo: CV. Hayati, 2008), hlm. 42

19M uhammad, M anajemen D ana Bank Syariah, (Yokyakarta: Ekosinia, 2004), hlm. 1

20Karnaen Perwataatmadja dan Syafi'i Antonio, Apa dan Bagaimana Bank Islam, (Yokyakarta: PT. Dana Bhakti Wakaf, 1997), hlm. 1

21Bank Indonesia, Perbankan Syariah $\mathrm{N}$ asional; Kebijakan dan perkembangan, (Jakarta: Bank Indonesia, 2001), hlm. 5.
} 
Adapun target pencapaian pengembangan sistem perbankan syarî'ah nasional adalah: Pertama, memiliki daya saing yang tinggi dengan tetap berpegang pada nilai- nilai syarî'ah. Kedua, memiliki peran signifikan dalam sistem perekonomian nasional serta perbaikan kesejahteraan rakyat. Ketiga, memiliki kemampuan bersiang secara global dengan pemenuhan standar operasional keuangan internasional.

Kenyataan menunjukkan bahwa dalam periode krisis ekonomi, perbankan syarî'ah memiliki daya saing dan daya tahan yang lebih kuat. Berkaitan dengan itu, perbankan syarî'ah diharapkan dapat berperan lebih besar dalam proses pemulihan perekonomian Indonesia yang masih terus berlangsung. Dalam upaya mendorong pertumbuhan industri perbankan syarî'ah yang masih berada dalam tahap awal pengembangan. Beberapa hal penting yang perlu mendapat perhatian antara lain, kerangka dan perangkat peraturan perbankan syarî'ah belum lengkap, cakupan pasar masih terbatas, kurangnya pengetahuan dan pemahaman mengenai produk dan jasa perbankan syarî'ah, institusi pendukung yang belum lengkap dan efektif, efisiensi operasional perbankan syarî'ah yang masih belum optimal, porsi skim pembiayaan bagi hasil dalam transaksi bank syarî'ah masih belum ditingkatkan, pemampuan untuk memenuhi standar keuangan syarî'ah internasional.

\section{Nilai-nilai Syarî'ah dalam Perspektif Mikro dan Makro}

Nilai-nilai syarî'ah dalam perspektif mikro menghendaki bahwa semua dana yang diperoleh dalam sistem perbankan syarî'ah dikelola dengan integritas yang tinggi dan sangat hati- hati. Kehatianhatian ini ditunjukkan dengan beberapa sikap, yaitu: Pertama, shiddîq memastikan bahwa pengelolaan bank syarî'ah dilakukan dengan moralitas yang menjunjung tinggi nilai kejujuran. Dengan nilai ini pengelola dana masayarakat akan dilakukan dengan mengedepankan cara- cara yang diperkenankan ( meragukan (subhât) terlebih lagi yang bersifat dilarang (haram). Kedua, tabligh, secara berkesinambungan melakukan sosialisasi dan mengedukasi masyarakat mengenai prinsip- prinsip, produk dan jasa perbankan syarî'ah. Dalam melakukan sosialisasi sebaiknya tidak hanya mengedepankan pemenuhan prinsip syarî'ah semata, tetapi juga harus mampu mengedukasi masyarakat mengenai manfaat bagi 
pengguna jasa perbankan syarî'ah. Ketiga, amânah, menjaga dengan ketat prinsip kehati-hatian dan kejujuran dalam mengelola dana yang diperoleh dari pemilik dana (shâhib al-mâl) sehingga timbul rasa saling percaya antara pihak pemilik dana dan pihak pengelola dan investasi (mudhârib). Keempat, fathanah, memastikan bahwa pengelolaan bank dilakukan secara professional dan kompetitif sehingga menghasilkan keuntungan maksimum dalam tingkat risiko yang ditetapkan bank. Termasuk didalamnya adalah pelayanan yang penuh dengan kecermatan dan kesantunan (ri'âyah) serta penuh rasa tanggung jawab (mas'ûliyah). 22

Sedangkan nilai-nilai syarî'ah dalam perspektif makro, berarti bahwa perbankan syarî'ah harus memberikan kontribusi bagi kesejahteraan masyarakat, melalui: Pertama, kaidah zakat, mengkondisikan perilaku masyarakat yang lebih menyukai berinvestasi dibandingkan hanya menyimpan hartanya. Hal ini dimungkinkan karena zakat untuk investasi dikenakan hanya pada hasil investasi sedangkan zakat bagi harta simpanan dikenakan atas pokoknya. Kedua, kaidah pelarangan ribâ, menganjurkan pembiayaan yang bersifat bagi hasil (equity based financing) dan melarang ribâ. Diharapkan produk-produk non ribâ ini akan mendorong terbentunya kecenderungan masyarakat untuk tidak bersikap memastikan dan bergeser ke arah sikap untuk berani menghadapi resiko. Ketiga, kaidah pelarangan judi atau maysir, tercermin dari kegiatan bank yang melarang investasi yang tidak memiliki kaitan dengan sektor riil. Kondisi ini membentuk kecenderungan masyarakat untuk menghindari spekulasi di dalam aktivitas investasinya. Keempat, kaidah pelarangan gharar, mengutamakan transpransi dalam bertransaksi dan kegiatan operasi lainnya dan menghindari ketidakjelasan.

Guna mendukung kegiatan operasional yang sehat, perbankan syarî'ah membutuhkan kerangka dan perangkat pengaturan yang sesuai dengan karakteristik operasionalnya. Di awal perkembangannya, kegiatan pengaturan dan pengawasan lembaga perbankan syarî'ah masih menggunakan kerangka pengaturan dan pengawasan sistem perbankan konvensional, walaupun beberapa instrument pengaturan telah mulai dikembangkan seperti perizinan

22lbid., hlm. 9. 
bagi pendirian bank dan pembukaan kantor, instrumen pasar keuangan antar bank, perangkat penghubung dengan otoritas moneter (sertifikat wadi'ah Bank Indonesia dan giro wajib minimum), dan sistem pembayaran (UUS wajib memiliki rekening di Bank Indonesia). Kurang lengkapnya instrumen pengaturan dan pengawasan tersebut akan mengakibatkan perbankan syarî'ah tidak dapat beroperasi secara optimal dan tidak sepenuhnya sesuai dengan karakteristiknya.

Guna menghadapi tantangan tersebut, Bank Indonesia selaku otoritas perbankan akan melakukan kajian, menyusun dan menyempurnakan instrumen pengaturan yang mencakup beberapa area utama, antara lain: (a) Penciptaan instrumen-instrumen keuangan serta aturan yang diharapkan akan dapat meningkatkan efisiensi operasional; (b) penyusunan peringatan dini (termasuk di dalamnya CAM EL rating system) yang dapat menggambarkan risiko operasional untuk menjamin kesinambungan perbankan syarî'ah yang berhati- hati serta konsep pelaporan yang transparan; dan (c) penyusunan rules of conduct bagi pelaku perbankan syarî'ah yang bertujuaan untuk meningkatkan kualitas corporate government.

Konsep pengaturan yang akan dikembangkan harus berorientasi pada upaya menjaga kestabilan sistem dan menjamin kepatuhan perbankan syarî'ah terhadap prinsip syarî'ah. Oleh karena itu kajian- kajian konseptual tentang pengaturan perlu dilakukan pada tahap awal pengembangan.

\section{Penutup}

UKM merupakan pelaku bisnis di tingkat yang paling bawah, karena itu pemberdayaan UKM dalam rangka menumbuhkan dan meningkatkan kemampuan usaha yang tangguh, mandiri, dan meningkat. Pendanaan UKM melalui bank syarî'ah merupakan pilihan yang tepat. Karena bank syarî'ah mempunyai peluang dalam rangka pengembangan perbankan guna memperbaiki perekonomian Indonesia.

\section{D aftar Pustaka}

Bank Indonesia, Perbankan Syariah Nasional; Kebijakan dan Perkembangan, (Jakarta: Bank Indonesia, 2001) 
Christianto, M odul Ekonomi; Untuk SMA/ M A Semester Genap sesuai Kurikulum KTSP, (Solo: CV. Hayati, 2008).

Isgiyarta, Jaka. M embangun Sinergi BANK- BUM N - U KM Problem dan Solusinya, makalah disampaikan dalam Forum Diskusi Ekonomi II Tahun 2004, (Semarang: 20 Juli 2004)

Jawa Pos, "Y ang Layak D apat Kredit M eningkat", (2 Januari 2008)

Muchammad Hariyanto, "Revitalisasi UKM dalam Membangun Ekonomi Nasional", Jurnal Manajemen BPFE Unversitas D iponegoro Semarang, (September 2002), hlm. 1

Muhammad, M anajemen Dana Bank Syariah, (Yokyakarta: Ekosinia, 2004)

Naim, Afrizal. Peranan Perbankan dalam Mempermudah Penyaluran K redit kepada U K M , makalah disampaikan dalam Forum Diskusi Ekonomi II Tahun 2004, (Semarang: 20 Juli 2004)

Perwataatmadja, Karnaen dan Antonio, Syafi'i. A pa dan Bagaimana Bank Islam, (Yokyakarta: PT. Dana Bhakti Wakaf, 1997).

Siregar, Mulya. Perbankan Syariah: Alternatif atau Pelengkap, makalah disampaikan dalam Seminar Nasional Shari'ate Economic Activity (SEHATI) di Universitas Diponegoro Semarang, (Semarang: 10 A gustus 2003).

Undang-undang N o. 23 Tahun 1999 tentang Bank Indonesia (Jakarta: Bank Indonesia, 1999)

Undang-undang Republik Indonesia N o. 9 tahun 1995 tentang Usaha Kecil, (Jakarta: Kementrian Koperasi dan UKM, 1995).

Widananto, Nanang. "Komitmen Memperkuat Daya Saing UKM", Jurnal Manajemen BPFE Unversitas Diponegoro Semarang, (Oktober, 2002) 